\title{
Macroeconomic Changes And Prices Stock In Real Estate And Property Firms
}

\author{
Rita Indah Mustikowati ${ }^{1}$, Sri Wilujeng ${ }^{2}$, M. Yusuf Kurniawan ${ }^{3}$ \\ 1,2 Program Studi Manajemen Universitas Kanjuruhan, Malang \\ ${ }_{3}^{3}$ Program Studi Manajemen Universitas Gajayana, Malang
}

\begin{tabular}{l} 
Article Info \\
\hline Article History: \\
Received : 30 Juni 2020 \\
Revised : 7 Juli 2020 \\
Accepted : 24 Juli 2020 \\
Keywords: \\
\hline
\end{tabular}

inflation, interest rate, price stocks

Kata Kunci:

Inflasi, suku bunga, harga saham

DOI:

\section{Correspondence:}

Name: Rita Indah Mustikowati

Email: ritaindah@unikama.ac.id

\section{Abstract}

The aim of this research is to explain the macroeconomic changes conditions on the stock prices of real estate and property firms. The sampling technique used was purposive sampling with a sample of 14 firms from 48 real estate and property firms that listed on the ISX. The analysis technique used is multiple regression. Based on the results of the analysis, it was found that the macroeconomic changes conditions, namely inflation, had no positive effect on the stock prices of real estate and property firms. This is because the amount of demand for real estate and property will increase in accordance with population growth. Other findings show that the interest rate proxied from the BI Rate has a negative effect on the stock prices of real estate and property firms. Increased interest rates from the BI Rate will cause investors to be no longer interested in investing in the money market because it is considered more profitable to invest with high interest rates.

\section{Abstraks}

Tujuan dari penelitian ini adalah untuk menjelaskan perubahan kondisi ekonomi makro terhadap harga saham perusahaaan real estate dan property. Teknik sampling yang digunakan adalah purposive sampling dengan jumlah sampel sebanyak 14 perusahaan dari 48 perusahaan real estate dan properti yang terdaftar di BEJ. Teknik analisis yang digunakan adalah regresi berganda. Berdasarkan hasil analisis, ditemukan bahwa perubahan kondisi ekonomi makro, yaitu inflasi, tidak berpengaruh positif terhadap harga saham perusahaan real estate dan property. Hal ini disebabkan karena jumlah permintaan akan real estate dan property akan semakin meningkat sesuai dengan pertumbuhan penduduk. Temuan lain menunjukkan bahwa suku bunga yang diproksikan dari BI Rate berpengaruh negatif terhadap harga saham perusahaan real estate dan property. Peningkatan suku bunga dari BI Rate akan menyebabkan para investor tidak tertarik lagi untuk berinvestasi pada pasar uang karena di anggap lebih menguntungkan berinvestasi dengan bunga yang tinggi. 


\section{INTRODUCTION}

A free trade will be pushes the firms level of competition sharper. The consequencies, a competition will be make a positive impact on the world economic growth. Economic resources limited will be exploited more efficiently. Facing in the free trade era, the capital market has an important role as a source of external financing for the business world and as a means of investment for the society (Hamrita \& Trifi, 2011; Sailendra \& Suratno, 2014). A capital market has become one of the success factors of the country's economic development. In addition, a capital markets will be a venue for lenders and capital seekers (borrower) to a raise funds from the public to be spend into a more productive sector (Brigham \& Houston, 2006). Through the estimation of excess funds they have, lenders will be expected to gain a rewards from the submission of such funds. On the other hand, the borrowers will use the funds investment without having to wait for the availability of funds from the firms operations. Generally, there are three main objectives of the market, there are; firstly, accelerate the process of expanding inclusion community in the ownership of the firms shares. Secondly, the income equality for the people and; third, increasing the people participation in gathering funds productively. Previous study has shown that there's some Indicators that can be considered for investors in investing, and one of it's an information about the stock price development (Ramadani, 2018).

A capital markets are one of the preferred alternative to a long-term funding sources among other firm alternatives (Barro, 1990; Qaisi, Al-qudah, \& Tahtamouni, 2016). Based on the development, the number of firm that sell its shares in the capital market is increasing. In relation to stock investing, investors will choose a firm stocks that are worthy to be selected based on specific criteria. The commonly criteria that used is stocks that are actively traded and it has a good fundamentals. The rational investors will be consider of two things, there are the expected income or expected return and the risk, whereby both of these are contained an alternative investments.

Stock market price is a market clearing prices which are determined based on the strength of demand and supply (Brigham \& Houston, 2006). So, stock price is the value of a share that reflects the wealth of the firm issuing the stock, where its change or fluctuation is determined by the power of supply and demand in the exchange (secondary market). When the investors want to buy or retain a stock, the price will be a rises. In contrast, the more investors who want to sell or release a stock, the price is increasingly moving down.

Theoretically, there are several perspectives that investors can use in predicting the change in the stock price, i.e. foreign exchange rate, interest rate, inflation and financial ratios. In line with that argument, Mishkin (2008), stated that the firm portfolio theory shows that there's a many factors influencing the request of a valuable letter, one of it's macro economic variables which consist of interest rates, rates, and inflation rates. Further, Mishkin (2008) also explains that marketable securities will be influenced by the firm profitability, expected inflation and government activities.

Inflation is the price of goods and services increase that have a broad influence as well as the price of shares in the capital market. The investors ability in understanding and predicting macroeconomic conditions in the future will be very useful in making profitable investment decisions. For that reason, investor should consider some macroeconomic indicators that can help in making investment decisions.

Empirically, some research has show a results that many people are interested to invest their funds in the real estate and property sector because of the price that tends to always rise (Geriadi \& Wiksuana, 2017; Ramadani, 2018). The price increase in the real estate and property sector because the soil supply is fixed. On the other hand, along with the increase in population and the increasing human needs of housing, offices, shopping centers, amusement parks and others, causing demand for this sector has always increased. Departing from these conditions, some developer firm will try to increase profits as the impact of the property's price increase. With the increased profits gained, the developer firm can improve its financial 
performance, so it can increase the stock price.

However, the nature of investments in the real estate and property sector are a long term and very sensitive growth. Some of a macroeconomic indicators, such as gross domestic product, inflation rate, interest rates and exchange rate, should be the thing that will determine the investment success. Considering some factors that affect the activity of the stock market that further leads to the increase and decrease in the number of stock requests and offers on the stock exchanges and the effect of changing the stock price, the information will be an important role for investors (Ramadani, 2018). The Information about the firm can be obtained from internal and external parties. External parties relating to the economic conditions of domestic and political situations, interest rates, government policies, inflation and others. While that affects the trading transactions of shares in internal parties, among others, related to the stock price, the level of profit gained, the level of risk, the firm performance and corporate action that the firm doing.

Stock price is the price that formed from the interaction of the sellers and buyers of stocks that are backed by their hopes of the firm profit (Mok, 1993). The stock price that occurs most recently in a single exchange day or which can be called the closing price. Stock prices are formed from the process of requests and offers occurring in the exchange. The increase or decrease of traded stocks on the exchange floor are determined by market forces. If the market assesses that the firm shares the stock in good condition, then usually the stock price of the firm will be a rises. Whereas if the firm is low-rated by the market, then the stock price of the firm will be decrease, even lower than the price in the secondary market. Therefore, the relationship between investors with the others strongly determine the stock price of the firm. From this reason, investors needed an information related to the establishment of the stock price in making decisions to sell or buy stocks.

Theoretically, Brigham \& Houston (2006) explained that there are several factors that affect the price of stocks that are, (1) fundamental factors, provide information about the firm performance and the factors that can affect it, including the management ability to manage the operational activities of the firm, the firm business prospects in the future, the marketing prospects of the business undertaken, the development of technology used in the firm operations, and the (2) Technical factors, describing the market an effect either individually or in groups in assessing the price of shares, such as the development of exchange rate, the state of the capital market, the volume and frequency of transactions of interest rates, and the strength of the capital market in influencing the stock price of the firm.

Economic risk analysis is a part of a stock analysis based on technical analysis. Analysis of external and macro factors in the form of events that occur outside the firm and affect all firm so that it cannot be controlled by the firm. The movement of economic direction affects the capital market movement which is useful for investor decision making. Good growth is good news for investors, so it positively affects the capital market (Weston \& Copeland, 2008).

Previous research shows that stock prices will be influenced by macroeconomic conditions (Demir, 2019; Hussain, Aamir, Rasool, Fayyaz, \& Mumtaz, 2012). Furthermore, that authors explained that there are several macro economic conditions that causes the change in the stock price, for example, inflation and interest rates. Inflation is the tendency of prices to increase generally and continuously. Basically, inflation can be distinguished between permanent and temporary (Mankiw, 2007). The core inflation rate is the rate of inflation due to the increasing pressure of demand for goods and services or aggregate demand in the economy.

The inflation rate is determined by the power of demand and supply reflecting the behaviour of market actors and the public. One of the factors affecting society's behaviour is their expectation of the future rate of inflation. High inflation expectations will encourage people to transfer their financial assets into real assets and vice versa. High inflation will result in decreased stock prices. This is because high inflation causes the price of goods to be generally increased. This condition affects the increase in production costs and then affects the selling price of high goods (Nurdin, 1999). That condition can be occur because the high price of goods will 
result in the purchasing power of the community that decreases and affects the level of profit of the declining firm and will eventually affect the price of the stock that also decreased. In line with that argument, (Soebagiyo, 2017) explained that inflation has a positive effect for the IDX because inflation is followed by the increase in the amount of money circulating in a propotional manner, demonstrating a good economic performance.

A large rate of inflation shows that the risk of investing in all major business sectors is, because high inflation will reduce the rate of return from investors. In addition, a high inflation conditions will be affect a tendency on the increase the price of goods. The increase of the price for these items will make the high cost production, so it will affect the decline in the number of requests individually or thoroughly. As a result, the number of sales will decline, and automatically it will decreasing the amount of sale and the firm revenue. Furthermore, it will adversely affect the firm performance reflected by the decline in the stock price of the firm (Nurdin, 1999).

Studies conducted by Suyati (2015) explaining that the interest rate is the annual interest payment of a loan, in the form of a percentage of the loan earned by the amount of interest received annually divided by the loan amount. Definitively, the interest rate described as is the price loan (Sunariyah, 2003). Interest rates are expressed as a percentage of principal money per unit time. Interest is a measure of the resource price used by debtor to be paid to creditors. The interest rate itself is determined by two strengths, namely: the savings supply and capital investment demand or especially from the business sector. Savings are the difference between revenue and consumption. Essentially, interest is the main drivers for the community to be willing to saving. The amount of savings will be determined by the high low interest rate. The higher interest rate will be triggers the public to save, and vice versa. High low investment fund offerings are determined by the high low interest rate of community savings. If the interest rate rises, it will give negative influence on the equity market. The decrease in interest rate will reduce the burden of the issuer and further increase the share price. The decrease in interest rate could encourage investors from savings to the capital market (Mardiyati \& Rosalina, 2013).

Based on the explanation, hypotheses in this study can be explained as follows:

H1. Inflation will be influence to the price of the real estate and property sector .

$\mathrm{H} 2$. Interest rates will be influence to the stock price of real estate and property sectors

\section{RESEARCH METHOD}

\section{Population and Sample}

The population in this research is the company's real estate and property listed in the Indonesia Stock Exchange (IDX). The population in this study consist of 48 real estate firm and the property listed on the stock exchange. The sam-pling techniques used are purposive sampling with sampling criteria covering the real estate and pro-perty firm that listed in Indonesia Stock Exchange (IDX). The basis of population determination in the study because in the period of 20142016, real estate and property firm have an experienced a fairly good development. The firm issued a complete financial statement from 2014 to 2016 and ended in the December 31st period to facilitate the research process. So that the number of real estate and property firm that become sample is 14 firm.

\section{Research Variables}

The variables used in this research are the stock prices of real estate companies and property that have reported complete financial statements in the period 2014-2016. The price stock referred to in this study is closing price, because it is this price that states the increasing and decreasing of a stock. Stock price Data is the average closing price three days after the date of publication as calculated from 2014 year until 2016. Furthermore, the stock price will be determined as a dependent variable $(\mathrm{Y})$.

Inflation rate $(\mathrm{X} 1)$ is the increase tendency of the price of goods which stated in percentage using the year inflation calculation, namely by comparing the index of the month with the index in December of the previous year which was processed from the annual report of $\mathrm{BI}$ and the financial economic statistics of Indonesia. With the measurement formula of percentage. The interest rate $(\mathrm{X} 2)$ is proscribed on the BI Rate 
is a policy interest rate reflecting the attitude or stance of monetary policy established by the Indonesian bank and announced to the public

\section{Data Source}

The data used in this research is secondary data, which is numeric data, which is physically observed, classified according to the place and time behind the events such as financial statements (Sugiyono, 2004). Completely, the data required in this research is the stock price data of 2014 - 2016, 2014-2016 inflation data and interest rate data from 2014-2016. The data sources in this research are obtained from IDX corner, Indonesian Capital Market Directory (ICMD), Central Bureau of Statistics (BPS) and Indonesian Bank.

\section{Data Analysis}

The research aims to determine the influence of macroeconomic conditions on stock prices. The macroeconomics are measured from the inflation rate $(\mathrm{X} 1)$ and interest rate (X2) proscribed from the BI Rate. To conduct testing of the proposed hypothesis, this study will be conducted with multiple regression analysis techniques. Data processing is done using SPSS software version 15 for Windows (Basuki, 2015).

\section{RESULT}

Results of multiple regression analyses of the influence between inflation (X1) and interest rates $(\mathrm{X} 2)$ on the stock price $(\mathrm{Y})$, obtained the following equation::

$$
\mathrm{Y}=1,488+0,287 \mathrm{X}_{1}+1,139 \mathrm{X}_{2}+\mathrm{e}
$$

Based on that equation above shows that if the inflation variable (X1) and the interest rate variable $(\mathrm{X} 2)$ are 0 (zero), then the stock price variable $(\mathrm{Y})$ is 1.488 . Meanwhile, inflation variable regression coefficient value of 0.287 indicates that when the inflation addition of $1 x$, it will increase the share price by 0.287 , assuming that the interest rate is constant. While the variable regression coefficient of 1.139 interest rate stated that each increase in interest rate of $1 x$ will increase the share price by 1.139 assuming that inflation is con- stant.

The results also indicate that the value of the correlation coefficient (R) is 0.314 which means that the relationship between variable $\mathrm{X}$ to $\mathrm{Y}$ is less closely. While coefficient of determination (R2) is obtained by 0099 which means that the contribution of macroeconomic variables with interest rates and inflation to the share price of $9.9 \%$, and the remaining $90.1 \%$ is influenced by other factors that are not researched in this study. The coefficient of determination has been adjusted (Adjusted R2) obtained by 0.052 , which means that the variation in the value of the share price $(\mathrm{Y})$ can be explained via the interest rate variable (X1) and inflation (X2), amounting to 5.2\% and the remaining $94.8 \%$ is influenced by other variables not examined in this study.

Based on the multicoliniearity test results with tolerance value $>0.1$ and the VIF < 10 , it can be concluded that the overall independent variables including inflation (X1) and interest rates (X2) do not have a multicolinearity relationship and can be used to predict profit during the research period. Based on the autocorrelation test results showed that Durbin-Watson's yield amounted to 2,588 . This indicates that there is no autocorrelation in the data because the results of Durbin-Watson are between 2.46-2.90. Based on the results of heteroskedasticity test can be seen randomly spread points, does not form a clear pattern and is spread over the numbers 0 and Y. This indicates that there is no heteroskedastisity. The normality test indicates that data is spreading around the diagonal line and following the direction of the diagonal line so that the research data can be said to meet the normality assumption.

The effect of independent variables on dependent variables, both simultaneously and partially, can be determined based on the results of the ANOVA test or F test with SPSS 15 for Windows. Based on the test results obtained that the value F count is 2.132 with significance level 0.132 . Since the probability $0.132>5 \%$, then it can be said that the inflation variable $(X 1)$ and the interest rate variable $(X 2)$ have no significant effect on the stock price $(\mathrm{Y})$.

Tabel 1. ANNOVA 


\begin{tabular}{clc}
\hline No. & \multicolumn{1}{c}{ Nama Perusahaan } & Market Share (\%) \\
\hline 1 & PT. Indofood Sukses Makmur Tbk & 40 \\
2 & PT. Wing's Food & 25 \\
3 & PT. Siantar Top & 10 \\
4 & PT. Garuda Food & 5 \\
& Jumlah & 100 \\
\hline
\end{tabular}

Sumber: Majalah Marketing (2018)

Based on t-test result indicates that the inflation variable has $t$-count of 1.137 with significance of 0.263 . Due to the probability of $0.263>5 \%$, it can be concluded that inflation variable (X1) as a partially has no significant effect on the price stock (X2). While the interest rate variable $(\mathrm{X} 2)$ has a t-count of 0.927 with significance of 0.360 . Due to the proba-bility of $0.360>5 \%$, it can be concluded that interest rate variable (X2) as a partially has no significant effect on the stock price $(\mathrm{Y})$.

Tabel 2. Coefficients

\begin{tabular}{|c|c|c|}
\hline No. & Nama Perusahaan & Market Share (\%) \\
\hline 1 & PT. Indofood Sukses Makmur Tbk & 40 \\
\hline 2 & PT. Wing's Food & 25 \\
\hline 3 & PT. Siantar Top & 10 \\
\hline 4 & PT. Garuda Food & 5 \\
\hline & Jumlah & 100 \\
\hline
\end{tabular}

Sumber: Marketing Magazine (2018)

\section{Discussion}

Overall, this research has resulted in several findings. Based on the results of a description of the analysis of macroeconomic variables that were measure by inflation and interest rates on the stock price of companies listed on the Jakarta Stock Exchange (JSX) from 2014 - 2016, indicating that the inflation and interest rates fluctuate from the increased to decreased. This shows that the Board of Governors sees the determination of the interest rate to control the level of inflation towards the medium-term inflation target and is conducive to maintaining the high momentum of economic growth. The interest rate is valid during the third quarter, but there's no possibility to become an adjustment in subsequent months in line with the economic development and overall monetary condition. Since interest rates become a reference instrument, the benefits of implementing BI Rate is the market participants do not need to speculate wildly against the change of $\mathrm{BI}$ Rate. They just make a prediction about how much the changes of Bi Rate. Maybe, they can prediction the changes of BI Rate approximately as 25 point or multiples. The increase or decrease of the BI Rate, depending on inflation trend and capital market conditions.
The results of a partial statistical test of the influence of inflation rate on the stock price have a coefficient value of 0.263 and simultaneously at 0.132 . In addition, both of partially and simultaneous, the BI Rate have a coefficient value of 0.360 . Therefore, the level of siginifansi exceeds 0.05 so the rate of inflation and the BI Rate has no influence on the stock price. It is in accordance with the research conducted by Park (1997) and Mok (1993).

Based on the above discussion, it can be concluded that the overall macroeconomic conditions have no significant effect on the stock price. This is because investors or prospective investors will see the firm internal information in advance for decision making buying or selling securities on IDX. In addition, the types of real estate and property firm, mostly are not affected by macro economy because of the fixed supply and demand is increasing related to the needs that must be met with the development of population increasing. In addition to the supply and demand conditions for investment in the real estate sector and the property is also encouraged by increasing human needs of housing, offices, shopping centers, amusement parks and others. It is proper if the developer firm can gain a profit from the price increase of 
real estate and the property. With the profit gained, the developer firm can be improve its financial performance so as to boost the stock price.

Macroeconomic conditions are improving, should make the financial performance of the real estate and property sector is getting better because with the decline in interest rates and inflation can increase the purchasing power of society. In this case, the developer can increase the number of transactions on the real estate and property offered. The increasing number of transactions will increase the financial performance of real estate and property firm which reflected in the firm financial statements. Improving the macroeconomic indicators has not yet revealed its effect on increasing the volume of real estate and property sales. This condition may be doubtful of many real estate and property investors to make an investments, thus it will raising the questions about the predictions about the real estate business and property which can be used as a guideline to invest securely in real estate and property stock.

\section{CONCLUSION}

Based on the results of multiple regression test macro economic conditions i.e. inflation has no positive effect on the stock price of real estate and property firms because the number of requests for real estate and property will be increased according to population growth. While BI Rate negatively affects the stock price of real estate and property firms. Increased BI Rate will cause the investors to not be interested anymore to invest in the money market because it is considered more profitable investing with high interest.

Based on the research, discussion, and research limitation, there can be some suggestions. The stock of real estate and property firms are one of the stocks that are sensitive to macroeconomic indicators. Therefore it's advisable for investors, in addition to considering the fundamental factors in the firms financial ratios and the systematic risk, the investors should be consider another factors that affect the stocks price, such as macroeconomic factors, currency exchange rate and others. The study uses only 2 macroeconomic variables, so it's advisable for the future researcher to adding another variable that is suspected to affect the stock price.

\section{REFERENCE}

Barro, R. J. (1990). The Stock Market and Investment. Review of Financial Studies, 3(1), 115-131. https://doi.org/10.1093/rfs/3.1.115

Basuki, Agus. Tri. (2015). Penggunaan SPSS dalam Statistik (Edisi Pertama). Danisa Media, Sleman.

Brigham, E., \& Houston, J. F. (2006). Fundamental of Financial Management (Tenth Edit). USA: Thomson South Westren College publishing.

Demir, C. (2019). Macroeconomic determinants of stock market fluctuations: The case of BIST-100. Economies, $\quad 7(1)$. https://doi.org/10.3390/economies701 0008

Geriadi, M. A. D., \& Wiksuana, I. G. B. (2017). Pengaruh Inflasi Terhadap Return Saham Pada Perusahaan Properti Dan Real Estate Yang Terdaftar Di Bursa Efek Indonesia (Risiko Sistematis Dan Profitabilitas Sebagai Variabel Mediasi). E-Jurnal Ekonomi Dan Bisnis Universitas Udayana, $\quad 9, \quad 3435$. https://doi.org/10.24843/eeb.2017.v06.i 09.p10

Hamrita, M. E., \& Trifi, A. (2011). The relationship between interest rate, exchange rate and stock price: A wavelet analysis. International Journal of Economics and Financial Issues, 1(4), 220228.

Hussain, M. M., Aamir, M., Rasool, N., Fayyaz, M., \& Mumtaz, M. (2012). The impact of macroeconomic variables on stock prices: An empirical analysis of Karachi stock exchange. Mediterranean Journal of Social Sciences, 3(3), 295-312. https://doi.org/10.5901/mjss.2012.v3n3 p295

Mankiw, N. G. (2007). Makroekonomi (Keenam). Jakarta: Erlangga.

Mardiyati, U., \& Rosalina, A. (2013). Analisis Pengaruh Nilai Tukar, Tingkat Suku Bunga dan Inflansi Terhadap Indeks Harga Saham. Jurnal Riset Manajemen Sains Indonesia (JRMSI), 4(1), 1-15.

Mishkin, F. (2008). Ekonomi Uang, Perbankan 
dan Pasar Keuangan (8th ed.). Jakarta: Salemba Empat.

Mok, H. M. (1993). Causality of interest rate, exchange rate and stock prices at stock market open and close in Hong Kong. Asia Pacific Journal of Management, 10(2), 123-143. https://doi.org/10.1007/BF01734274

Nurdin, D. (1999). Resiko investasi pada saham property di BEJ. Usahawan, 3, XXVIII.

Park, S. (1997). Rationality of negative stockprice responses to strong economic activity. Financial Analysts Journal, 53(5), 52-56.

https://doi.org/10.2469/faj.v53.n5.2117

Qaisi, F. Al, Al-qudah, M., \& Tahtamouni, D. A. (2016). Factors Affecting the Market Stock Price - The Case of the Insurance Companies Listed in Amman Stock Exchange. International Journal of Business and Social Science, 7(10), 81-90. https://doi.org/ISSN: 2219-1933

Ramadani, F. (2018). Pengaruh Inflasi, Suku Bunga Dan Nilai Tukar Rupiah Terhadap Harga Ssaham Perusahaan Sektor Properti Dan Real Estate Yang Tercatat Di Bursa Efek Indonesia. Manajemen Bisnis, 6(1), 72-82. https://doi.org/10.22219/jmb.v6i1.5392
Sailendra, \& Suratno. (2014). Faktor-Faktor Fundamental, Kondisi Makro Ekonomi dan Return Saham Perusahaan Pertambangan di Bursa Efek Indonesia. Jurnal Riset Akuntansi Dan Perpajakan, 1(1), 1-14.

Soebagiyo, D. (2017). Peranan Pendapatan Riil, Tingkat Bunga Dan Inflasi Dalam Fungsi Permintaan Uang. Jurnal Ekonomi Pembangunan: Kajian Masalah Ekonomi Dan Pembangunan. https://doi.org/10.23917/jep.v4i1.4015 Sugiyono. (2004). Metode Penelitian. CV. Alfabeta: Bandung.

Sunariyah. (2003). Pengantar Pengetahuan Pasar Modal (Ketiga). Yogyakarta: UPPAMP YKPN.

Suyati, S. (2015). Pengaruh Inflasi,Tingkat Suku Bunga Dan Nilai Tukar Rupiah/Us Dollar Terhadap Return Saham Properti Yang Terdaftar Di Bursa Efek Indonesia. Serat Acitya-Jurnal Ilmiah UNTAG Semarang, 4(3), 2302-2752.

Weston, J. F., \& Copeland, T. E. (2008). Manajemen Keuangan. Jakarta: Binarupa Aksara.

www.bi.go.id tentang BI Rate dan Kurs US \$ www.bps.com tentang tingkat inflasi dan Produk Domestik Bruto 